\title{
Clinico-Haematological Study of Pancytopenia
}

\author{
Samira Taufique Reshma *1, Susane Giti², Shahed Ahmed Chowdhury ${ }^{3}$, \\ Mohammad Golam Rabbani ${ }^{4}$, Mohammad Iqbal Kabir ${ }^{5}$, Md. Atiqul Islam Rabby ${ }^{6}$
}

\section{Abstract}

Introduction: Pancytopenia is a clinical condition, which refers to a combination of anaemia, leucopenia and thrombocytopenia. It often poses diagnostic challenge to physician and the knowledge of accurate etiologies of this condition is crucial in the management of the patient. Materials and Methods: The study was a prospective study done over a period of October 2011 to December 2011 and 50 patients were evaluated clinically along with haematological parameters, bone marrow aspiration and wherever required, a trephine biopsy was performed in Haematology department of Armed forces institute of pathology (AFIP), Dhaka cantonment, Dhaka. In all patients, a detailed relevant history along with a physical examination was done and data was collected using pre designed proforma. Results: Among the 50 cases studied, age of the patients ranged from 3 to 80 yrs with a mean age of 37.5 yrs and male predominance. Fever and generalized weakness were the most common symptoms. The commonest physical findings were pallor followed by splenomegaly and hepatomegaly. Anisopoikilocytosis and relative lymphocytosis was the most prominent peripheral blood findings in patients. The commonest cause of pancytopenia was Aplastic anaemia (36\%), followed by Myelodysplastic syndrome (18\%), visceral leishmaniasis (12\%), Megaloblastic anaemia (8\%), Acute leukaemia (6\%), Myelofibrosis (4\%), Multiple myeloma (4\%), Hypersplenism (4\%), Malaria (2\%). Conclusion: As a large number of pancytopenic patients have a reversible aetiology, early \& proper diagnosis may be life saving. Maximum diagnostic yield can be achieved by correlation with clinical findings \& laboratory parameters.

Keywords: Pancytopenia, Bone marrow examination, Aplastic anaemia.

Number of Tables: 05; Number of Figures: 02; Number of References: 44; Number of Correspondence: 03.

*1. Corresponding Author:

Dr. Samira Taufique Reshma, MBBS, FCPS

Asst. Professor \& Head of Haematology

Chattogram Ma O Shishu Hospital Medical College

Agrabad, Chattogram.

e-mail: iqbalkabir61@gmail.com

2. Major General (Prof.) Susane Giti MBBS, DCP, MCPS, FCPS

Commandant, Armed Forces Institute of Pathology

Dhaka Cantonment, Dhaka.

3. Prof. Dr. Shahed Ahmed Chowdhury

Professor, Department of Haematology

Chattogram Medical College \& Hospital, Chattogram.

4. Prof. Dr. Mohammad Golam Rabbani

MBBS, FCPS (Haematology)

Professor \& Head, Department of Haematology

Chattogram Medical College \& Hospital, Chattogram.

5. Lt. Col (Dr.) Mohammad Iqbal Kabir

BDS, D-OMS, MCPS, FCPS

MDC Sylhet, Jalalabad Cantonment.

6. Dr. Md. Atiqul Islam Rabby, BDS

Lecturer, Marks Medical College (Dental Unit)

Dhaka, Bangladesh.

Email:atiqul.rabby@gmail.com

\section{Introduction:}

Pancytopenia is an important clinico-haematological entity encountered in our day to day clinical practice. There are varying trends in its clinical pattern, treatment modalities and outcome ${ }^{1}$.

The incidence of pancytopenia around the world is not mentioned in the textbook. Different studies done at different places showed variable frequency of pancytopenia. The study conducted by Shazia Memon et $\mathrm{al}^{2}$ in Hyderabad within three years periods showed, $3.57 \%$, while Habibur Rehman et $\mathrm{al}^{3}$, Kanchanalak et $\mathrm{al}^{4}$ and Adil et $\mathrm{al}^{5}$ reported $0.8 \%, 1.2 \%$ and $12.6 \%$ respectively. The aetiology of pancytopenia varies in different populations depending on the differences in age patterns, nutritional status, climate and the prevalence of infections ${ }^{6}$.

It is always present in some stages in the course of aplastic anaemia, very common in subleukaemic leukaemia, relatively uncommon in lymphoma and rare in metastatic carcinoma involving the bone marrow. The prognosis depends on the severity of pancytopenia and on the nature of underlying pathology?

Pancytopenia is not a disease entity but a triad of findings that may result from various disease processs, which can be defined by reduction in all three formed elements of blood below the normal reference range ( Haemoglobin $<13.5 \mathrm{gm} / \mathrm{dl}$ in males or $11.5 \mathrm{gm} / \mathrm{dl}$ in females, Leucocyte count $<4 \times 10^{9} / \mathrm{L}$ and Platelet count $\left.<150 \times 10^{9} / \mathrm{L}\right)^{8}$.

The presenting clinical symptoms are usually due to anaemia, leucopenia and thrombocytopenia. Fatigue and weakness due to anaemia, increased susceptibility to infections because of leucopenia 
and bleeding tendency due to thrombocytopenia are the usual presenting symptoms ${ }^{9}$.

Red blood cell indices help us to classify anaemias as microcytic, normocytic, and macrocytic depending on low, normal or high MCV. Most of the causes of pancytopenia present with normal RBC indices, but causes like megaloblastic anaemia, aplastic anaemia, myelodysplastic syndrome and paroxysmal nocturnal hemoglobinuria presents with high $\mathrm{MCV}^{10}$.

Bone marrow examinations, such as bone marrow aspiration and biopsy, are extremely helpful in the evaluation of pancytopenia ${ }^{11}$. The bone marrow picture may vary depending on the etiology, from normocellular with non-specific changes to hypocellular, hypercellular or being replaced completely by malignant cells. According to aetiology, degree and duration of the bone marrow impairment, clinically these can lead to fever, pallor, infection or serious illness and death. Knowing the exact etiology is important for specific treatment and prognostication $^{12}$.

Few clear recommendations can be found as to the optimal investigative approach to pancytopenia. Some experts suggest that marrow examination is essential to the diagnosis, but it has not been established whether the procedure is necessary in all pancytopenic patients. Bone marrow aspiration is one of the most frequent and relatively safe, invasive procedure done routinely to evaluate the cause. Though an invasive procedure, it can be easily performed even in the presence of severe thrombocytopenia with little or no risk of bleeding. This study was carried out with the aim to obtain detailed information of a common disorder in our set-up regarding its causes and diagnostic approaches and there by automatically enhance the management process.

Early diagnosis of various causes of pancytopenia are very crucial and require prompt clinical examination and investigations like complete blood count, peripheral blood flim study and bone marrow examination. In Bangladesh the causes of pancytopenia are not well defined, for this purpose, this study will be helpful to findout the underlying etiopathology of pancytopenia.

\section{Materials and Methods:}

This study was a prospective study conducted at Armed Forces Institute of Pathology (AFIP), Dhaka cantonment, Dhaka from October to December 2011. Total 50 patients presenting with pancytopenia were found out by using a preformed questionnaires and blood counts obtained prior to transfusion done on an automated haematology analyzer. In all patients, a detailed relevant history including the treatment history, history of drug intake, radiation exposure, along with a physical examination of pallor, jaundice, hepatomegaly, splenomegaly and lymphadenopathy, were taken. Peripheral blood film study was done by staining the blood smears with leishman stains.

\section{Peripheral Smear Preparation and Staining}

Peripheral smear was prepared and stained according to the guidelines in Practical Hematology, Dacie and Lewis, 10th Edition ${ }^{13}$.

\section{Bone Marrow aspiration ${ }^{14}$}

Under aseptic measures aspiration was done through posterior iliac crest. The patient was placed in a prone position, a pillow under their head. Lidocaine was used as the anaesthetic, providing the patient has no history of an allergic reaction to this medication. During this process, local anaesthetic is first infiltrated into the skin and subcutaneous tissue to anaesthetize an area approximately $1 \mathrm{~cm}$. in diameter. After the skin is numb, lidocaine is infiltrated directly over the periosteum to numb an area approximately $2-3 \mathrm{~cm}$ in diameter. Salah needle is advanced with steady pressure and a slight twisting motion to the center of the posterior iliac prominence. The needle was rotated back and forth $\left(90^{\circ}-180^{\circ}\right)$ and careful pressure was applied to advance the needle through the cortical bone. A decreased resistance indicated penetration of cortex and entry into the marrow cavity. Needle was advanced about $1 \mathrm{~cm}$ into the marrow cavity. The obturator was unlocked and slowly removed $0.3 \mathrm{ml}$ of marrow fluid was aspirated into a $10 \mathrm{ml}$ syringe and specimen slides were prepared. A folded piece of gauze was placed over the site with a pressure bandage. The patient was asked to lie supine for at least 30 minutes.

\section{Steps of preparing aspirated smear and staining methods ${ }^{13}$}

Prepared slides were examined under scanner and low power to assessed cellularity, megakaryocytes and metastatic carcinoma cells. The area where cells were very well spread out was selected and under oil immersion at least 500 marrow cells were counted.

\section{Bone Marrow Biopsy ${ }^{15-17}$}

The bone marrow biopsy was obtained through the same skin incision site used for the marrow aspiration. Jamshidi needle was used for this procedure. Once the needle fixed in the bone, the stylet was removed. Using firm pressure, slowly rotate the needle in an alternating clockwisecounterclockwise motion and advance it into the bone marrow cavity to obtain an adequate bone marrow specimen measuring approximately $1.5-2 \mathrm{~cm}$ in length. Needle was rotated along its axis to help cut the specimen. Following this procedure slowly pulled the needle out rotating in an alternating clockwise and counterclockwise motion. Then, removed the specimen from the needle with the probe through the distal cutting end. If the aspiration was a dry tap, the core biopsy may be used to make touch preparations prior to placing the specimen in fixative. Obtained material kept in $10 \%$ formalin. After the procedure, pressure was applied for a 2 minutes and an elastoplast was applied after placing the gauze on the top of the site. The patient was instructed to check the site frequently, to report any bleeding, and to keep it dry. The dressing was removed after 48 hours only. Biopsy 
specimen stained with haematoxylin and eosin (H\&E). Prepared slides were examined under microscope.

\section{Ethical Consideration}

Ethical clearance was obtained from the Research Committee of DGMS office. Permission to use the records was obtained from the Haematology department of AFIP, Dhaka. Written informed consent was taken from the patient's or legal guardian for the use of any photographs. Patient confidentiality was strictly maintained. No names, addresses or contact details of the patients were divulged.

\section{Method of data processing \& statistical analysis}

Data were analyzed by using Microsoft excel \& statistical analysis was done by using descriptive statistics.

Results:

Among all study patient $80 \%$ patients are male and $20 \%$ are female. Male to female ratio was $4: 1$. The most common causes (figure 1) of pancytopenia was aplastic anaemia $(36 \%)$, followed by $\operatorname{MDS}(18 \%)$, and visceral leishmaniasis (12\%). Other less common causes of pancytopenia include acute leukaemia (12\%), megaloblastic anaemia (8\%), myelofibrosis, Hypersplenism, multiple myeloma (each one constitute $4 \%)$. Uncommon causes in this study was malaria $(2 \%)$. Maximum number of patients was found in the age group (Table I) of 11-20 years and incidence of aplastic anaemia, ALL was more in 11-20 yrs of age. Similarly MDS was more in 61-70 yrs of age and AML \& megaloblastic anaemia was more in 51-60 yrs.
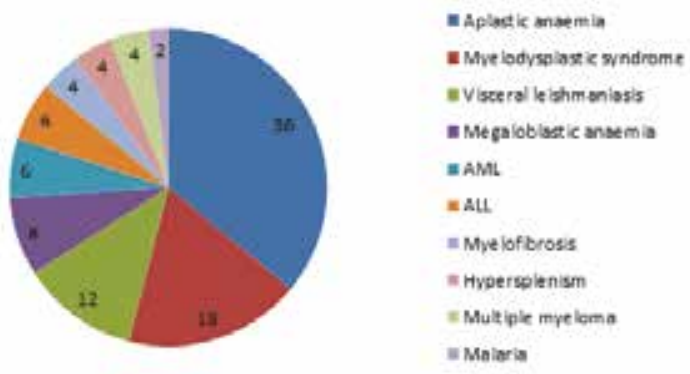

Figure 1: Different causes of pancytopenia.

Table I: Age and etiology wise distribution.

\begin{tabular}{lcccccccc}
\hline $\begin{array}{l}\text { Age in } \\
\text { yrs }\end{array}$ & $\begin{array}{l}\text { Aplastic } \\
\text { anaemia }\end{array}$ & MDS & $\begin{array}{l}\text { Viscearal } \\
\text { leishmaniasis }\end{array}$ & AML & ALL & $\begin{array}{l}\text { Megaloblastic } \\
\text { anaemia }\end{array}$ & $\begin{array}{l}\text { Multiple } \\
\text { myeloma }\end{array}$ & $\begin{array}{c}\text { Misc } \\
\cdot\end{array}$ \\
\hline $0-10$ & 3 & 0 & 1 & 0 & 1 & 0 & 0 & 0 \\
$11-20$ & 4 & 0 & 2 & 0 & 2 & 0 & 0 & 1 \\
$21-30$ & 3 & 1 & 2 & 0 & 0 & 0 & 0 & 1 \\
$31-40$ & 3 & 0 & 1 & 1 & 0 & 1 & 1 & 0 \\
$41-50$ & 1 & 0 & 0 & 0 & 0 & 1 & 1 & 1 \\
$51-60$ & 2 & 1 & 0 & 2 & 0 & 2 & 0 & 1 \\
$61-70$ & 2 & 4 & 0 & 0 & 0 & 0 & 1 & 1 \\
$71-80$ & 0 & 3 & 0 & 0 & 0 & 0 & 0 & 0 \\
\hline
\end{tabular}

MDS-Myelodysplastic syndrome, AML- Acute myeloblastic leukaemia ALL- Acute lymphoblastic leukaemia, Misc.- Myelofibrosis, Malaria, Hypersplenism

The bone marrow study showed that (Table II) 36\%of the patients had hypocellular marrow, $60 \%$ had cellular marrow including normocellular marrow $(6 \%)$ and hypercellular marrow (54\%) and 4\% had blood tap. Increased erythropoiesis seen (Table II) in $44 \%$ cases. Decreased erythropoiesis seen in $38 \%$ cases and normal erythropoiesis seen in $14 \%$ cases, $32 \%$ cases was showed dyserythropoiesis. Granulopoiesis decrease in most cases of $(32 \%)$ aplasic anaemia. Whereas increases granulopoiesis seen in 28\% cases (MDS 12\%, megaloblastic anaemia $8 \%$, acute leukaemia $6 \%$, visceral leishmaniasis $2 \%$ ). Twenty study (40\%) cases also showed normal granulopoiesis. Dysgranulopoiesis was seen, only in cases of $\operatorname{MDS}(10 \%)$. Decreased megkaryopoiesis (Table II) seen in $48 \%$ cases. Increased megkaryopoiesis seen in $12 \%$ cases and normal megakaryopoiesis seen in $32 \%$ cases. Dysmegkaryopoiesis was seen in patients having $\operatorname{MDS}(14 \%)$ and megaloblastic anaemia (4\%). Overlap of common haematological parameters in major causes of pancytopenia without any clue to diagnosis. However, more severe anaemia, leucopenia and thrombocytopenia were found in cases of visceral leishmaniasis (Table III).

Table II: Cellularity, Erythropoiesis, Granulopoiesis \& Megakaryopoiesis in different causes of pancytopenia.

\begin{tabular}{lcccc}
\hline Condition & Hypocellular & Normocellular & Hypercellular & Blood tap \\
Cellularity & $18(36 \%)$ & $3(6 \%)$ & $27(54 \%)$ & $2(4 \%)$ \\
\hline Condition & Normal & Increased & Decreased & Dyerythropoiesis \\
Erythropoiesis & $7(14 \%)$ & $22(44 \%)$ & $19(38 \%)$ & $16(32 \%)$ \\
Granulopoiesis & $20(40 \%)$ & $14(28 \%)$ & $18(26 \%)$ & $5(10 \%)$ \\
Megakaryopoiesis & $16(32 \%)$ & $6(12 \%)$ & $24(48 \%)$ & $9(18 \%)$ \\
\hline
\end{tabular}

Table III: Mean hematological parameters in five common cause of pancytopenia.

\begin{tabular}{lllccccc}
\hline \multicolumn{1}{c}{ Disease } & $\begin{array}{c}\text { Hb } \\
\text { g/dl }\end{array}$ & $\begin{array}{c}\text { Total } \\
\text { Count(x10^9/L) }\end{array}$ & $\begin{array}{c}\text { Platelets } \\
\text { Count(x10^9/L) }\end{array}$ & $\begin{array}{c}\text { ESR } \\
\mathbf{m m}\end{array}$ & $\begin{array}{c}\text { MCV } \\
\text { fl }\end{array}$ & $\begin{array}{c}\text { MCH } \\
\mathbf{p g}\end{array}$ & MCHC \\
\hline $\begin{array}{l}\text { Aplastic } \\
\text { anaemia }\end{array}$ & 7.93 & 2.49 & 34.97 & 88.6 & 83.5 & 28.54 & 33.77 \\
MDS & 8.03 & 3.01 & 62.55 & 80.22 & 82.8 & 28.28 & 34.13 \\
$\begin{array}{l}\text { Visceral } \\
\text { leishmaniasis }\end{array}$ & 6.02 & 2.83 & 43.66 & 100.8 & 70.71 & 25 & 31 \\
$\begin{array}{l}\text { Acute } \\
\text { leukaemia }\end{array}$ & 7.62 & 2.41 & 62.16 & 109 & 85 & 29 & 33.33 \\
$\begin{array}{l}\text { Megaloblastic } \\
\text { anaemia }\end{array}$ & 8.31 & 2.25 & 85.25 & 83.5 & 90.8 & 29 & 35.12 \\
\hline
\end{tabular}

The most common clinical complaint in this study was fever $30(60 \%)$, followed by general weakness (figure 2). Fever affects all patients of visceral leishmaniasis \& generalized weakness was more common in cases of aplastic anaemia. Pallor as a clinical sign was universal (70\%), followed by splenomegaly $(30 \%)$ which was more often seen in all patients of visceral leishmaniasis (figure 2). Table IV shows comparison of peripheral blood film findings of different diseases of present study with other studies done by Gayathri and Rao et $\mathrm{al}^{1}$ and Tilak V et $\mathrm{al}^{18}$. Table V shows comparison of first and second causes of pancytopenia in different studies with present study. 


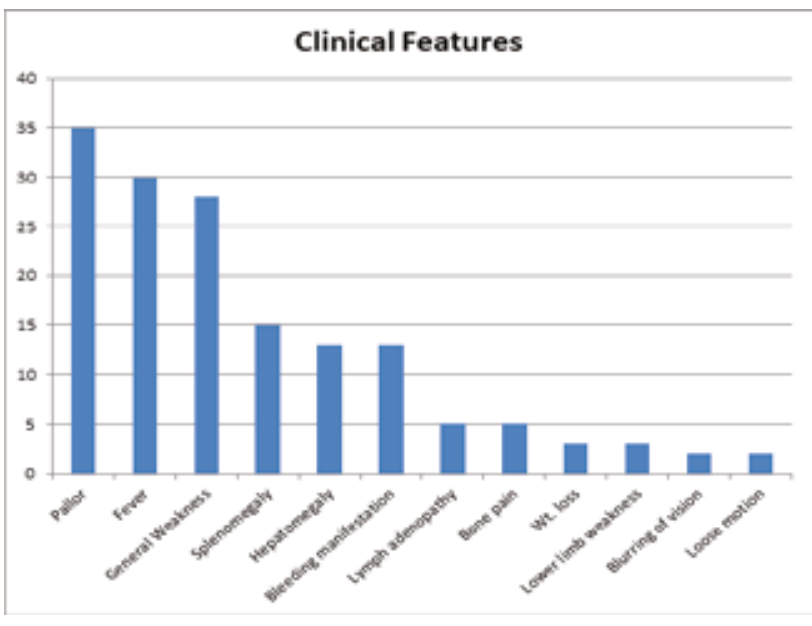

Figure 2: Clinical features according to causes of pancytopeni

Table IV: Comparison of peripheral blood findings with those in other studies.

\begin{tabular}{|c|c|c|c|c|c|c|c|c|c|c|c|c|c|c|c|c|c|c|}
\hline \multirow[t]{2}{*}{ Diagnosis } & \multicolumn{3}{|c|}{$\begin{array}{c}\text { Total no of } \\
\text { cases }\end{array}$} & \multicolumn{3}{|c|}{$\begin{array}{c}\text { Anisopoikiloc } \\
\text { ytosis }\end{array}$} & \multicolumn{3}{|c|}{ NRBC } & \multicolumn{3}{|c|}{$\begin{array}{l}\text { Hypersegment } \\
\text { ed neutrophils }\end{array}$} & \multicolumn{3}{|c|}{$\begin{array}{c}\text { Immature } \\
\text { WBC }\end{array}$} & \multicolumn{3}{|c|}{$\begin{array}{c}\text { Relative } \\
\text { lymphocytosis }\end{array}$} \\
\hline & $\mathbf{A}$ & B & $\mathrm{C}$ & $\mathbf{A}$ & B & $\mathrm{C}$ & $\mathbf{A}$ & B & $\mathbf{C}$ & $\mathbf{A}$ & B & C & $\mathbf{A}$ & B & $\mathrm{C}$ & $\mathbf{A}$ & B & $\mathrm{C}$ \\
\hline $\begin{array}{l}\text { Aplastic } \\
\text { anaemia }\end{array}$ & 18 & 19 & 6 & 1 & 17 & 2 & - & - & - & - & 5 & - & 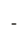 & - & - & 12 & 10 & 3 \\
\hline MDC & ? & 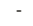 & - & 7 & 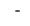 & - & 4 & - & - & 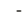 & - & 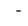 & & - & - & 1 & - & 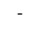 \\
\hline $\begin{array}{l}\text { Visceral } \\
\text { leishmaniasis }\end{array}$ & 6 & - & - & 2 & - & - & - & - & - & - & - & - & - & - & - & 1 & - & - \\
\hline & 6 & 4 & 1 & - & 1 & 1 & 1 & 1 & 1 & - & - & - & 6 & 2 & 1 & - & - & - \\
\hline $\begin{array}{l}\text { Megaloblasti } \\
\text { c anaemia }\end{array}$ & 4 & 77 & 53 & 2 & 68 & 51 & 1 & - & 13 & 2 & 38 & 45 & - & 20 & - & - & - & - \\
\hline $\begin{array}{l}\text { Multiple } \\
\text { myeloma }\end{array}$ & 1 & 1 & 1 & - & 1 & 1 & 1 & - & - & - & - & - & - & - & - & - & - & - \\
\hline Malaria & 1 & 2 & 3 & 1 & 2 & 1 & - & - & - & - & - & - & - & - & - & - & - & - \\
\hline
\end{tabular}

A- Present study

B- Study done by Gayathri and Rao et $\mathrm{al}^{1}$

C- Study done by Tilak V et $\mathrm{al}^{19}$.

Table V: A comparison of the first and second most common causes of pancytopenia.

\begin{tabular}{|c|c|c|c|c|c|}
\hline Study & Country & Year & $\begin{array}{l}\text { No of } \\
\text { cases }\end{array}$ & $\begin{array}{l}\text { Commonest } \\
\text { causes }\end{array}$ & $\begin{array}{l}\text { Second most } \\
\text { common cause }\end{array}$ \\
\hline Keisu \& Ost ${ }^{20}$ & $\begin{array}{l}\text { Israel \& } \\
\text { Europe }\end{array}$ & 1990 & 100 & $\begin{array}{l}\text { Neoplastic disease, } \\
\text { radiation }(32 \%)\end{array}$ & $\begin{array}{c}\text { Aplastic } \\
\text { anaemia }(19 \%)\end{array}$ \\
\hline Hossain et a $1^{18}$ & Bangladesh & 1992 & 50 & $\begin{array}{l}\text { Aplastic } \\
\text { anaemia }\end{array}$ & $\begin{array}{c}\text { Cr. Malaria \& } \\
\text { Cr. Kalazar }\end{array}$ \\
\hline Verma \& Das ${ }^{11}$ & India & 1992 & 202 & $\begin{array}{c}\text { Aplastic } \\
\text { anaemia }(40.6 \%)\end{array}$ & $\begin{array}{l}\text { Megaloblastic } \\
\text { anaemia(23.26\%) }\end{array}$ \\
\hline Tilak \& Jain ${ }^{19}$ & India & 1999 & 77 & $\begin{array}{l}\text { Megaloblastic } \\
\text { anaemia }(68 \%)\end{array}$ & $\begin{array}{c}\text { Aplastic } \\
\text { anaemia }(7.7 \%)\end{array}$ \\
\hline Kumar et $\mathrm{al}^{21}$ & India & 1999 & 166 & $\begin{array}{c}\text { Aplastic } \\
\text { anaemia }(29.51 \%)\end{array}$ & $\begin{array}{c}\text { Megaloblastic } \\
\text { anaemia }(22.3 \%)\end{array}$ \\
\hline Khodke et al ${ }^{22}$ & India & 2000 & 50 & $\begin{array}{l}\text { Megaloblastic } \\
\text { anaemia (44\%) }\end{array}$ & $\begin{array}{c}\text { Aplastic } \\
\text { anaemia }(14 \%)\end{array}$ \\
\hline $\begin{array}{l}\text { International } \\
\text { arganulocytosis } \\
\text { and aplastic } \\
\text { anemia study } \\
\text { group }^{23}\end{array}$ & $\begin{array}{l}\text { Israel \& } \\
\text { Europe }\end{array}$ & 1987 & 319 & $\begin{array}{c}\text { Aplastic } \\
\text { anaemia }(52.7 \%)\end{array}$ & $\begin{array}{r}\text { Myelodysplastic } \\
\text { syndrome (4.5\%) }\end{array}$ \\
\hline Present study & Bangladesh & 2011 & 50 & $\begin{array}{c}\text { Aplastic } \\
\text { anaemia }(36 \%)\end{array}$ & $\begin{array}{l}\text { Myelodysplastic } \\
\text { syndrome }(18 \%)\end{array}$ \\
\hline
\end{tabular}

\section{Discussion:}

Pancytopenia is not an uncommon hematological problem encountered in our clinical practice and should be suspected on clinical grounds when a patient presents with unexplained anaemia, prolonged fever and tendency to bleed $^{24}$. There are varying reports on the underlying aetiology of pancytopenia from various parts of the world ${ }^{25}$.

In present study among 50 patients with pancytopenia 40 were males and 10 were females, with male: female ratio of $4: 1$. It was $2.6: 1$ in the study done by Lakhey et al, ${ }^{26}$ and $2: 1$ in the study by Mussarrat Niaze and Fazil-i-Raziq ${ }^{27}$. In this study of pancytopenic patients the highest incidence was in the age group of 11-20 years,followed by 41-60 yrs of age. Mussarrat Niaze and Fazil-i-Raziq in their study also found most common age group of pancytopenia in the range from 12-30 years ${ }^{27}$. The mean age was 37.5 years with a range of 3-80 years. Osama Ishtiaq et $\mathrm{al}^{24}$ and Gayathri $\mathrm{B} \mathrm{N}$ et $\mathrm{al}^{1}$. in their studies found mean ages to be 36.7 years and 41 years respectively. Lakhey et $\mathrm{al}^{26}$ also found the mean age was 40 years in their study.

The commonest cause of pancytopenia in present study was Aplastic anaemia (36\%). Table V shows comparison of 1 st and 2 nd most common causes common causes of pancytopenia in different studies conducted in different countries $^{11,19,23}$. Hypoplastic anaemia was commonest cause of pancytopenia. However, in some studies hypoplastic anaemia was next to megaloblastic anaemia and latter was the commonest cause of pancytopenia ${ }^{19,22}$. But in a study done by Keisu et $\mathrm{al}^{20}$ neoplastic disease was the commonest cause of pancytopenia, unlike present study in which it was third in the list. The high frequency of malaria and kalazar in their study may be due to study done in an endemic area. In our study 6 cases of pancytopenia showed leishmaniasis and malaria was detected in 1 case. Only a single study showed MDS as the second commonest cause of pancytopenia ${ }^{23}$ like present study. The incidence of aplastic anaemia quoted from west is $10-25 \%{ }^{28}$. In present study Aplastic anaemia was the predominant causes of pancytopenia (36\%), similar to study conducted by Deepak B Kumar et $\mathrm{al}^{28}$ $(33.33 \%)$, Jha et $a 1,{ }^{29}(29.5 \%)$. Aplastic anaemia was the commonest causes of pancytopenia in some studies ranging from $24 \%-49 \%$ and the second cause in other studies. High incidence of aplastic anaemia was reported in Philippine $(54 \%)^{30}$ and Nepal $(30 \%)^{31}$. In those two studies, males were affected with aplastic anaemia much more than females which might be a result of a higher incidence of occupational exposure to chemicals and pesticides $^{32}$; the reverse is seen in Iraqi rural community as females use these substances more than males ${ }^{28}$.

Over $60 \%$ of patients are over the age of 70 at diagnosis, with males more likely to be diagnosed with MDS than females by a ratio of $1.4: 1 .^{33}$ Similarly in present study all the cases of MDS was found within the age group of $61-70 \mathrm{yrs}$, with male, female ratio was $2: 1$. The incidence of MDS as a cause of pancytopenia was $8.33 \%$ in a study conducted by Deepak B kumar et $\mathrm{al}^{28}$. while in present 
study MDS was the 2nd most common causes of pancytopenia (18\%).

Visceral leishmaniasis was the third most common causes of pancytopenia in present study as found in $12 \%$ cases. Similar findings was reported by Najlaa Badir Al-Awadi et $\mathrm{al}^{34}$. All the cases of visceral leishmaniasis were from Gajipur, Dhaka, near the endemic zone of this disease, in Bangladesh. Sud A et al. ${ }^{35}$ and Sever-Prebilic M et al. ${ }^{36}$ have reported the presence of visceral leishmaniasis in non -endemic areas. So, if there is pancytopenia with history of splenomegaly and fever one should think of visceral leishmaniasis even if patient is not from endemic area or not exposed to such area. Visceral leishmaniasis is one of the common cause of pancytopenia and frequency is very high in some studies done in India and Pakistan ${ }^{37}$.

The incidence of megaloblastic anaemia in other studies varied from $0.8 \%$ to $68 \%{ }^{28}$. This wide variation of incidence of megaloblastic anaemia depends on the status of the nutritional anaemia in that particular region of the study. The incidence was $8 \%$ in present study, most of the cases was found between the age group of 51-60 yrs and all the cases were male. Out of 4 patients 1 had evidence of malabsorption syndrome, and the remaining 3 cases the underlying disorder could not be established and evaluation of serum folate or vit B-12 was not available in this study.

Pancytopenia can be seen in $30 \%$ cases of acute leukaemia at the time of presentation ${ }^{22}$. Acute leukaemia constituted $12 \%$ of total cases of pancytopenia in present study which is low as compared to study of Jha et $\mathrm{al}^{29}$. in which it constituted $19.59 \%$ of total cases of pancytopenia. However, in study of Deepak B Kumar et $\mathrm{al}^{28}$ no cases of acute leukaemia was detected and in study of Tilak et al ${ }^{19}$ only 1 case of acute leukaemia was detected as a cause pancytopenia. On the other hand in the study of Bashwari et $\mathrm{al}^{38}$ the main indication of bone marrow examination (BME) in case of pancytopenia was investigation of acute leukaemia. Acute leukaemia constituted third most common cause of pancytopenia in the study of Savage et $\mathrm{al}^{39}$ and similar finding was seen in study of Varma and Dash $^{11}$. In the study of Aziz et $\mathrm{al}^{40}$ acute leukaemia constituted almost $10 \%$ of cases of pancytopenia and was third most common cause of pancytopenia.

In France, Imbert et $\mathrm{al}^{41}$ founded myelofibrosis on bone marrow biopsy of adult patients with pancytopenia in $31 \%$ of them; while in present study, only $4 \%$ cases of myelofibrosis was found and all the cases were was diagnosed by bone marrow trephine biopsy.

Erythroid hyperplasia was present $4 \%$ cases of the present study and Splenomegaly was seen in both the cases of erythroid hyperplasia in present study. Some of these cases may represent one phase in the evolution of hypoplasia, while some may be cases of refractory anemia. The criteria for differentiation of these groups remain unsatisfactory and these patients should be kept under follow-up. Hypercellular or normocellular marrow in cases of pancytopenia can also be seen in cases with ineffective hematopoiesis with cell death within the marrow. Similarly, hypercellular marrow in the presence of peripheral pancytopenia can be a manifestation of myelodysplastic syndrome ${ }^{29}$. Focal hyperplasia of erythroid or granulocytic cells at a similar stage of maturation may be observed in hot spot. A correlation with BME, clinical parameters and other laboratory parameters are required to trace the cause of pancytopenia in these cases. A possible hypersplenism needs to be ruled out in addition to different haemolytic anaemias in cases of marrow showing erythroid hyperplasia ${ }^{42}$.

The annual incidence of Multiple myeloma is 4 per $1,00,000$. It represents approximately $1 \%$ of all malignant diseases and $15 \%$ of all haematological malignancies. The incidence of $\mathrm{MM}$ is lower in Asian populations and in blacks is twice that in whites; $\mathrm{MM}$ is slightly more frequent in men than in women. The median age at diagnosis is $65-70$ years. Only $15 \%$ and $2 \%$ of the patients are younger than 50 and 40 years, respectively ${ }^{43}$. In present study of the remaining causes multiple myeloma accounted for 2 cases (4\%). The age of the patients with multiple myeloma were 45 and $65 \mathrm{yrs}$ and both were male. A single case was diagnosed as a cause of pancytopenia in the study done by Pathak et $\mathrm{al}^{42}$ and Jha et $\mathrm{al}^{29}$ which shows similarity to this study.

Pancytopenia, a decrease in all the three types of cells in the peripheral blood, commonly presents with symptoms of anaemia or thrombocytopenia. Leucopenia is an uncommon cause of the initial presentation of the patient, but can become fatal during the subsequent course of the disorder. Sometimes pancytopenia is detected as an incidental feature of a disorder that is capable of depressing the levels of all cellular elements in the blood ${ }^{28}$. Figure 2 shows that fever affects all patients of visceral leishmaniasis, while generalized weakness was most often seen in aplastic anaemia. Pallor as a clinical sign was universal in all case of aplastic anaemia, followed by splenomegaly which was found in all cases of visceral leishmaniasis. In another study by Niazi and Raziq weakness $(68.2 \%)$ was the commonest symptom, followed by fever $(47.7 \%)$ and bleeding manifestations $(33.7 \%)^{27}$. With reference to the commonest clinical sign that we came across, pallor was the most common sign, followed by pallor with splenomegaly and pallor with hepatosplenomegaly. In studies conducted by Khodke et $\mathrm{al}^{22}$, Deepak B Kumar et $\mathrm{al}^{28}$ and Niazi and Raziq ${ }^{27}$, pallor and hepatosplenomegaly were the commonest sign, as in the present study.

We found that the routine hematological parameters were non-specific and showed a significant overlap among the major causes of pancytopenias. Table III shows comparison of common haematological parameters in five major causes of pancytopenia. However, the peripheral 
blood films were valuable in pointing toward the cause in patients with megaloblastic anaemia and leukaemia. Bone marrow aspirate was found to be sufficient for diagnosis in most cases of leukaemia and megaloblastic anaemia. Peripheral blood flim findings of present study were comparable with those in other studies shown in Table IV hypersegmented neutrophils were noted in $50 \%$ cases of megaloblastic anaemia in present study, compared to $49.35 \%$ in Gayathri and $\mathrm{Rao}^{1}$ study and $84.9 \%$ in Tilak V et $\mathrm{al}^{19}$ study, but Khunger et $\mathrm{al}^{44}$ in their study demonstrated no hypersegmented neutrophils in megaloblastic anaemia. Also relative lymphocytosis in aplastic anaemia was noted in $66.66 \%$ caes in present study compared to $52.63 \%$ study done by Gayathri and Rao et $\mathrm{a}^{10}$ and $50 \%$ in study done by Tilak V et a ${ }^{19}$.

\section{Conclusion:}

The various causes of pancytopenia can be attributed to the geographic area, genetic differences, stringency of diagnostic criteria, and differences in methodology used. Aplastic anaemia is the most common cause of pancytopenia in this study. Severe pancytopenia has significant correlation with poor disease outcome and can be used as a prognostic indicator. There are varying trends in its clinical pattern, treatment modalities, and outcome depending on the different causes of pancytopenia which should kept in mind while managing it. Causes such as megaloblastic anaemia, and infections such as visceral leishmaniasis and malaria are reversible. As a large proportion of pancytopenia is of reversible etiology, early an accurate diagnosis may be life-saving.

\section{Conflict of Interest: None}

\section{Acknowledgement:}

The faculties of Haematology department of Armed forces institute of pathology (AFIP), Dhaka cantonment, Dhaka.

\section{References:}

1. Gayathri BN, Rao KS. Pancytopenia: a clinico hematological study. Journal of laboratory physicians. 2011 Jan;3(1):15.

https://doi.org/10.4103/0974-2727.78555

\section{PMid:21701657 PMCid:PMC3118050}

2. Memon S, Shaikh S, Nizamani MA. Etiological spectrum of pancytopenia based on bone marrow examination in children. J Coll Physicians Surg Pak. 2008 Mar 1;18(3):163-7.

3. Rehman HU, Fazil M, Khan FM. The etiology pattern of pancytopenia in children upto 15 years, Pak. Armed Forces Med. J. 2003;53(2):183-7.

4. Ghorpade K, Baldota S. Pancytopenia-its causes in Bombay. J JJ Group Hosp Grant Med Coll. 1991;33:30-2.

5. Adil S, Kakepoto GN, Khurshid M, Burney IA. Epidemiological features of aplastic anaemia in Pakistan. Journal of Pakistan Medical Association. 2001;51:443.
6. Santra G, Das BK. A cross-sectional study of the clinical profile and aetiological spectrum of pancytopenia in a tertiary care centre. Singapore medical journal. 2010 Oct 1;51(10):806.

7. Firkin F, Chesterman C, Penington D. Pancytopenia and aplasticanaemia. In de Gruchy's clinical haematology in medical practice. London, Blackwell Scientific Publications. 1989;88:119-36.

8. Ashalatha N, Netravathi P, Ragupathi A, Nagarajappa A. Hemogram and bone marrow morphology in cases of pancytopenia. The Internet Journal of Laboratory Medicine. 2010;4(2).

https://doi.org/10.5580/1684

9. Devi PM, Laishram RS, Sharma PS, Singh AM, Singh MK, Singh YM. Clinico-hematological profile of pancytopenia in Manipur, India. Kuwait med J. 2008 Sep $1 ; 40(3): 221-4$.

10. Qamar U, Aijaz J. Results of bone marrow examination in patients presenting with pancytopenia and high mean corpuscular volume. Gomal Journal of Medical Sciences. 2012 Jul 1;10(1).

11. Varma N, Dash S. A reappraisal of underlying pathology in adult patients presenting with pancytopenia. Tropical and geographical medicine. 1992 Oct;44(4):322. 12. Naseem S, Varma N, Das R, Ahluwalia J, Sachdeva MU, Marwaha RK. Pediatric patients with bicytopenia/pancytopenia: review of etiologies and clinico-hematological profile at a tertiary center. Indian Journal of pathology and microbiology. 2011 Jan 1;54(1):75.

https://doi.org/10.4103/0377-4929.77329

PMid:21393882

13. Bates I. Bone marrow biopsy. Lewis SM, Bain BJ, Bates I, Dacie JV. Dacie and Lewis practical haematology. Churchill Livingstone. 2006 Apr 28: 117-130.

https://doi.org/10.1016/B0-44-306660-4/50010-6

PMid:16959975

14. Jacobs P. Choice of needle for bone marrow trephine biopsies. HEMATOLOGY REVIEWS AND COMMUNICATIONS. 1995;9:163-168.

15. Bain BJ. Bone marrow trephine biopsy. Journal of clinical pathology. 2001 Oct 1;54(10):737-42.

https://doi.org/10.1136/jep.54.10.737

\section{PMid:11577117 PMCid:PMC1731298}

16. Vergidis D. Bone Marrow aspiration and Biopsy. Cancer. 2004 Jul 24; 46(1):173-7.

17. Riley RS, Jonathan M, Pavot DR. An illustrated guideline for bone marrow aspiration and biopsy. 2001 Jan 3;4:1-14.

18. Keisu M, Ost A. Diagnoses in patients with severe pancytopenia suspected of having aplastic anemia. European journal of haematology. $1990 \mathrm{Jul}$; 45(1):11-4.

https://doi.org/10.1111/j.1600-0609.1990.tb00407.x

PMid:2379559 
19. Tilak V, Jain R. Pancytopenia--a clinico-hematologic analysis of 77 cases. Indian journal of pathology \& microbiology. 1999 Oct;42(4):399-404.

20. Hossain MA, Akond AK, Chowdhary MK, Sikder AM, Rashid MA. Pancytopenia-A study of 50 cases. Bangladesh Journal of pathology. 1992;1:9-12.

21. Kumar R, Kalra SP, Kumar H, Anand AC, Madan H. Pancytopenia--a six year study. The Journal of the Association of Physicians of India. 2001 Nov 1;49:1078-81.

22. Khodke K, Marwah S, Buxi G, Yadav RB, Chaturvedi NK. Bone Marrow Examination in Cases of Pancytopenia. JIACM. 2001;2:55-59.

23. International agranulocytosis and aplastic anaemia study. Incidence of aplastic anaemia, the relevance of diagnostic criteria. Blood.1987;70:1718-21.

https://doi.org/10.1182/blood.V70.6.1718.bloodjournal706 1718

\section{https://doi.org/10.1182/blood.V70.6.1718.1718}

24. Ishtiaq O, Baqai HZ, Anwer F, Hussain N. Patterns of pancytopenia patients in a general medical ward and a proposed diagnostic approach. Journal of Ayub Medical College Abbottabad. 2004;16(1).

25. Khan FS, Hasan RF. Bone marrow examination of pancytopenic children. JPMA-Journal of the Pakistan Medical Association. 2012 Jul 1;62(7):660.

26. Lakhey A, Talwar OP, Singh VK, KC SR. Clinico-hematological study of pancytopenia. Journal of Pathology of Nepal. 2012;2(3):207-10.

https://doi.org/10.3126/jpn.v2i3.6023

27. Mussarrat Niazi M, Fazi-i-Raziq. The incidence of underlying pathology in Pancytopenia. JPMI 2004;18(1):76-79.

28. Kumar DB, Raghupathi AR. Clinicohematologic analysis of pancytopenia: Study in a tertiary care centre. Basic and Applied Pathology. 2012 Mar;5(1):19-21.

https://doi.org/10.1111/j.1755-9294.2011.01121.x

29. Jha A, Sayami G, Adhikari RC, Panta AD, Jha R. Bone marrow examination in cases of pancytopenia. $\mathrm{J}$ Nepal Med Assoc. 2008 Jan 1;47(169):12-7.

https://doi.org/10.31729/jnma.209

30. Lyn B, Irene RC, Marina DS. Clinico-hematologic and pathologic profile of adult Filipino pancytopenic patients. Turk J Hematol (Supplement). 2005;22.

31. Ratna MG. Study of clinical profile, causes, modalities of treatment and final outcomes of pancytopenia in Nepalese adult population (Doctoral dissertation, Thesis of Doctor of Medicine of Tribhuvan University, Kathmandu, Nepal).

32. Hamid GA, Shukry SA. Patterns of pancytopenia in Yemen. Turk J Hematol. 2008 Jun 5;25(2):71-4.
33. Timothy JT Chevassut and Ghulam J Mufti. The myelodysplastic Syndromes: In postgraduate haematology. Sixth edition.Oxford: A John Wiley \& Sons, Ltd, Publication; 2011:p 503-528.

https://doi.org/10.1002/9781444323160.ch28

34. Al-yasiri HH, Al-Awad AS, Al-Awadi NB. Patterns of Pancytopenia according to the Cause in Babylon. Medical Journal of Babylon. 2009;6(3-4):434-40.

35. Sud A, Varma N, Marwaha RK, Patel FM, Trehan A, Singh S, et al. Visceral leishmaniasis in a non-endemic area of India. Tropical doctor. 2004 Oct;34(4):247-9.

https://doi.org/10.1177/004947550403400426

PMid:15510962

36. Sever-Prebilic M, Prebilić I, Seili-Bekafigo I, Dokić S, Ivanis N, Nacinovic-Duletic A, et al. A case of visceral leishmaniasis in the Northern Adriatic region. Collegium antropologicum. 2002 Dec 16;26(2):545-50.

37. Dhingra KK, Gupta P, Saroha V, Setia N, Khurana N, Singh T. Morphological findings in bone marrow biopsy and aspirate smears of visceral Kala Azar: a review. Indian Journal of Pathology and Microbiology. 2010 Jan 1;53(1):96.

https://doi.org/10.4103/0377-4929.59193

PMid:20090232

38. Bashawri LA. Bone marrow examination. Indications and diagnostic value. Saudi medical journal. 2002 Feb;23(2):191.

39. Mudenge B, Savage DG, Allen RH, Gangaidzo IT, Levy LM, Gwanzura C, et al. Pancytopenia in Zimbabwe. The American journal of the medical sciences. 1999 Jan 1;317(1):22-32.

https://doi.org/10.1016/S0002-9629(15)40466-5

40. Aziz T, Ali L, Ansari T, Liaquat HB, Shah S, Ara J. Pancytopenia: megaloblastic anemia is still the commonest cause. Pak J Med Sci. 2010 Jan 1;26(1):132-6.

41. Imbert M, Scoazec JY, Mary JY, Jouzult H, Rochant $\mathrm{H}$, Sultan C. Adult patients presenting with pancytopenia: a reappraisal of underlying pathology and diagnostic procedures in 213 cases. Hematologic pathology. 1989 Jan 1;3(4):159-67.

42. Pathak R, Jha A, Sayami GI. Evaluation of bone marrow in patients with Pancytopenia. Journal of Pathology of Nepal. 2012;2:265-271.

https://doi.org/10.3126/jpn.v2i4.6875

43. Jes u s San - Miguel and Joan Blad e. Multiple myeloma. In: Postgraduate Haematology. Sixth edition. Oxford: A John Wiley \& Sons, Ltd, Publication; 2011:p577-597.

44. Khunger JM, Arulselvi S, Sharma U, Ranga S, Talib VH. Pancytopenia--a clinico haematological study of 200 cases. Indian journal of pathology \& microbiology. 2002 Jul;45(3):375. 